\title{
HD 121135: FEATURES OF ITS CHEMICAL COMPOSITION
}

\author{
T. Mishenina ${ }^{1}$, Usenko I. ${ }^{1,2}$, Kniazev A. ${ }^{3}$, Kovtyukh V. ${ }^{1}$ \\ ${ }^{1}$ Astronomical Observatory, Odessa National University, 65014-UA Odessa, Ukraine, \\ tmishenina@ukr.net
}

${ }^{2}$ Mykolaiv Astronomical Observatory, Obsevatorna 1,Mykolaiv 54030, Ukraine

${ }^{3}$ South African Astronomical Observatory, P.O. 7925, Cape Town, South Africa

ABSTRACT. Low metallicity star HD121135 ([Fe/H] = -1.5) have been investigated spectroscopically. Its atmospheric parameters and elemental abundances have been determined, including elements of neutron (n-) capture processes, which are the keys in the study of early Galaxy enrichment. $\mathrm{Na}, \mathrm{Mg}, \mathrm{Ni}, \mathrm{Co}, \mathrm{Sr}, \mathrm{Y}, \mathrm{Zr}, \mathrm{Mo}, \mathrm{Ba}, \mathrm{La}, \mathrm{Ce}, \mathrm{Pr}$, Sm, Eu, Gd, Dy, Ho, Os, Th abundances were calculated using the synthetic spectrum method, factoring in the hyperfine structure (HFS) for the Eu II lines. Si, Ca, Sc abundances were determined using the equivalent widths of their lines. The carbon content was computed by the molecular synthesis fitting for the region of $\mathrm{CH}$ (4300-4330 $\AA \AA$ ). For the abundances determinations of $\mathrm{C}, \mathrm{Na}, \mathrm{Mg}, \mathrm{Ba}$, and Th the NLTE corrections have been applied.

We have determined for the first time the abundances of several $n$-capture elements and found that the behaviors of these elements do not show a significant trend with increasing atomic number. The elements ratios of $[\mathrm{Eu} / \mathrm{Fe}]$ $=0.06,[\mathrm{Ba} / \mathrm{Eu}]=0.13,[\mathrm{Sr} / \mathrm{Ba}]=-0.05$ do not support the HD121135 status as a r-process enrichment star. We have obtained the thorium abundance $[\mathrm{Th} / \mathrm{Fe}]=0.26$. The carbon content confirms the effect of canonical additional mixing in this star.

Keywords: stars: abundances - stars: atmospheres - stars: Population II - stars: individual (HD 121135).

АНОТАЦІЯ. Хімічні елементи, що утворювалися в результаті процесів захоплення нейтронів (n-), $\epsilon$ ключовими у вивченні раннього збагачення Галактики. Їх великий вміст в зоряній атмосфері дозволяє тестувати процеси нуклеосинтезу. Перш за все, це важливо у випадку вивчення елементів швидкого захвату n (rпроцес), що віддзекалює, наприклад злиття нейтронних зірок або вплив магнітогідродинамічних наднових. Це також важливо для відстеження шляху збагачення цими елементами міжзоряного середовища в ранні галактичні часи. Для зірки HD121135 з металевістю [Fe / H] $=-1,5$ були визначені атмосферні параметри та розповсюдженність елементів.

Спектральний матеріал отримано за допомогою ешеле-спектрографа HRS Південноафриканського великого телескопа (SALT) у режимі середньої роздільної здатності ( $\mathrm{R}$ 31000-41000) з високим коефіцієнтом відношення сигнал до шуму, близько 100-200, в діапазоні довжин хвиль від 3900 до $8700 \AA \AA$ А. Атмосферні параметри та хімічний склад зірки HD 121135 були визначені в підході ЛТР (локальної термодинамічної рівноваги) з використанням моделей атмосфери Castelli \& Kurucz (2004). Вміст Na, Mg, Ni, Co, Sr, Y, Zr, Mo, $\mathrm{Ba}, \mathrm{La}, \mathrm{Ce}, \mathrm{Pr}, \mathrm{Sm}, \mathrm{Eu}, \mathrm{Gd}$, Dy, Ho, Os, Th розрахований за допомогою нової версії програмного забезпечення STARSP (Цимбал 1996), враховуючи надтонку структуру (HFS) для ліній $\mathrm{Eu} \mathrm{II,} \mathrm{а} \mathrm{вміст} \mathrm{Si}, \mathrm{Ca}, \mathrm{Sc}$ визначений 3 використанням єквівалентних ширин і WIDTH9 P. Куруча. Вміст вуглецю розраховано за допомогою припасування молекулярного синтезу до спостережного спектру в області СН (4300-4330 А̊).

Для вмісту $\mathrm{C}, \mathrm{Na}, \mathrm{Mg}, \mathrm{Ba}$ та Th ми розглянули оцінки поправок за рахунок відхилення від ЛТР.

Ми вперше визначили вміст деяких елементів нейтронного (n) захвату, включно з торієм, для HD121135. Ми виявили, що поведінка вмісту n- елементів не демонструє суттєвої тенденції росту зі збільшенням атомного числа. Співвідношення елементів $[\mathrm{Eu} / \mathrm{Fe}]=$ 0,06, $[\mathrm{Ba} / \mathrm{Eu}]=0,13,[\mathrm{Sr} / \mathrm{Ba}]=-0,05$ не підтримує визначення досліджуваної зірки як зірки зі збагаченням r-процесу. Ми отримали вміст торію зі значенням $[\mathrm{Th} / \mathrm{Fe}]=0,26$. Вміст вуглецю підтверджує ефект канонічного додаткового змішування (Денисенков та Пінсон, 2008) у досліджуваній зірці.

\section{Introduction}

Metal-poor stars $([\mathrm{Fe} / \mathrm{H}]<-1.0)$ are considered to be among the oldest existing stars in the Galaxy (Beers \& Christlieb, 2005; Frebel \& Norris, 2015). Observations of these stars may be given an opportunity to get the data about the early conditions of nucleosynthesis for the Galactic stars, especially about the nucleosynthesis of rare elements, yields from early mergers of neutron stars (NSM) and supernovae (SN), and the chemical evolution of theGalaxy in general.

The low content of metals, primarily for the iron, indicates the possible contamination of interstellar clouds by a small number of stars producing chemical elements, especially at the very first, early stages of the Galaxy, at which the mixing of matter was still insignificant. Stars enrichment by the elements of the fast (r-) neutron capture process are very important for understanding of the early Galaxy chemical evolution (Sneden et al., 1996, Yong et al., 2013; Roederer et al., 2014; Hansen et al., 2018).

The sources of of r-process elements production are in the active stage of researches. There are some transactions 
that strongly support an early mergers of neutron stars (NSM) hypotheses (e.g. Lattimer \& Schramm, 1974; Rosswog et al. 2014; Lippuner et al., 2017), but other authors suggest that not only NSMs can produce (create) rprocess elements (e.g. Tsujimoto \& Nishimura, 2015). At the same time, standard core-collapse supernovae most likely cannot produce the basic elements of the r-process (Arcones \& Thielemann, 2013); however, the most likely candidate for yet another r-process formation site could be core-collapsed supernovae from strong magnetic stars (e.g. Winteler et al. 2012; Nishimura et al. 2017).

The study of r-process-enhanced, metal-poor stars are useful for identifying of the r-process sources types.

Besides, in this case, the detection of radioactive elements like Th and $\mathrm{U}$ is high, that provide cosmochronometric ages can also be determined (see, e.g., Holmbeck et al. 2018 and references therein).

The r-process-enhanced, metal-poor stars have historically been divided into two main categories (Beers \& Christlieb 2005): the r-I stars have $0.3<=[\mathrm{Eu} / \mathrm{Fe}]<=+1.0$, while $r$-II stars have $[\mathrm{Eu} / \mathrm{Fe}]>+1.0$; both require $[\mathrm{Ba} / \mathrm{Eu}]<0$ to avoid contamination from the s-process. Variations in the lighter neutron-capture elements, such as $\mathrm{Sr}, \mathrm{Y}$, and $\mathrm{Zr}$, have been observed in several stars (e.g., Spite et al. 2018) and a new limited $\mathrm{r}$ - process designation with $[\mathrm{Sr} / \mathrm{Ba}]>+0.5$ to classify stars with enhancements in these lighter elements was proposed by Frebel (2018). A subset of r-II stars ( 30\%) also exhibit an enhancement in $\mathrm{Th}$ and $\mathrm{U}$ that is referred to as an "actinide boost" (e.g., Hill et al., 2002; Mashonkina et al., 2014; Holmbeck et al., 2018a) - a complete explanation for this phenomenon remains elusive.

The main aim of this work is to study the elements abundances that have been formed due to n-capture processes in the atmosphere of HD 121135 , with $[\mathrm{Fe} / \mathrm{H}]$ near -1.5 . This object is one of the stars from our project to study the sources (sites) of r-process enrichment in the early Galaxy.

\section{Observations and spectrum processing, radial ve-} locities

The main characteristics of HD 121135 (HIP 67822) were taken from the SIMBAD database, in particular: Equatorial coordinates: $\alpha=1353$ 33; $\delta=+024141$ (2000) (GAIA DR2); Galactic coordinates: 336.90; +61.40 (2000).

Stellar magnitudes: $\mathrm{B}=10.14 ; \mathrm{V}=9.37$ (SIMBAD); distance $=755.00 \mathrm{pc}($ GAIA DR2); parallax (mas): 1.3245 [0.0532] (GAIA DR2); radial velocity (RV) in $\mathrm{km} / \mathrm{s}=$ 125.60 [0.23] (GAIA DR2).

One spectrum of this star was obtained in 2020 with the 11-metre Southern African Large Telescope (SALT) (Buckley et al., 2006; O’Donoghue et al., 2006) and fibrefed dual-beam echelle-spectrograph HRS (Barnes et al., 2008, Bramall et al., 2010, Bramall et al., 2012, Crause et al., 2014) in the medium resolution mode ( $\mathrm{R} \sim 31000$ 41000 ) with a single exposure of 650 s and a high $\mathrm{S} / \mathrm{N}$ ratio near 100-200. HRS allows to provide the spectrum in the blue and red arms over the total spectral range from 3900 to $8700 \AA \AA$. Primary reduction of HRS data, including overscan correction, bias substractions and gain corrections, was done with SALT science pipeline (Crawford et al., 2010).
All the data were processed using the software package developed by the authors based on the standard system of astronomical data reduction MIDAS. Further spectra processing, such as the continuum establishment, line depth and equivalent width (EW) measurements, etc., was conducted using the DECH30 software package by G.A. Galazutdinov http://gazinur.com/DECH-software.html. The radial and rotational velocities were measured by fitting of the observed spectra with models from Coelho (2014).

\section{Atmosphere parameters determination}

To determine the effective temperature Teff, we have precised the value of $\mathrm{T}_{\text {eff }}$ based on the independence of the iron abundance obtained from given lines from the lower-level potential $E_{\text {low }}$ of this line (Fig. 1). Gravity log $\mathrm{g}$ was determined from the ionization equilibrium balance for the Fe I and Fe II abundances. The microturbulent velocity $\mathrm{Vt}$ was obtained from the condition of independence Fe I abundance on the equivalent width EW (Fig. 2).

The metallicity $[\mathrm{Fe} / \mathrm{H}]$ was adopted as the iron abundance determined from the Fe I lines. The selection of the parameters was performed using an iterative procedure. Finally, the following parameters were adopted: $\mathrm{T}_{\mathrm{eff}}=$ $4950 \mathrm{~K} ; \log \mathrm{g}=1.5 ; \mathrm{V}_{\mathrm{t}}=1.8 \mathrm{~km} / \mathrm{s}$

Table 1 represents the comparison results of our data with those from other works. As can be seen in Table 1, there is a good agreement between $\mathrm{T}_{\text {eff }}$, and $[\mathrm{Fe} / \mathrm{H}]$ obtained by different authors. However, some discrepancies are evident for $\log \mathrm{g}$ and turbulent velocity $\mathrm{Vt}$ values.

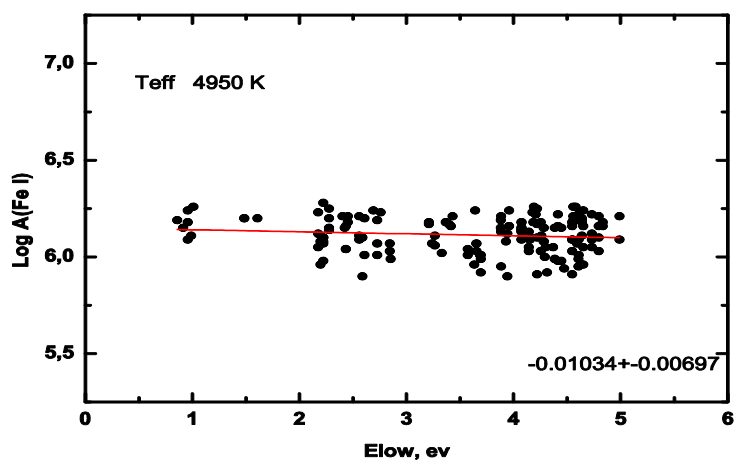

Figure 1. The dependence of $\log \mathrm{A}(\mathrm{Fe} \mathrm{I})$ on $\mathrm{E}_{\text {low }}$

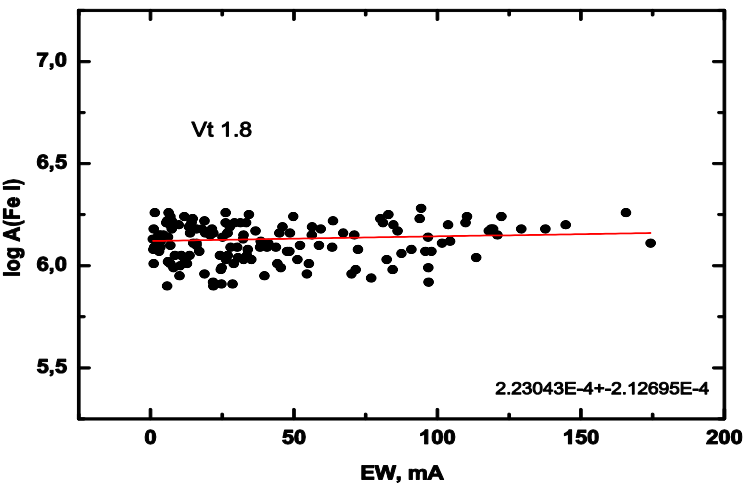

Figure 2 . The dependence of $\log \mathrm{A}(\mathrm{FeI})$ on EW. 
Table 1. Comparison of parameters obtained by different authors

\begin{tabular}{|c|c|c|c|c|}
\hline $\mathbf{T}_{\text {eff }}$ & $\log \mathrm{g}$ & {$[\mathrm{Fe} / \mathrm{H}]$} & $\mathrm{Vt}, \mathrm{km} / \mathrm{s}$ & reference \\
\hline 4950 & 1.5 & -1.47 & 1.8 & our \\
\hline 4934 & 1.91 & $\begin{array}{l}-1.54 \\
-1.37 \\
\end{array}$ & 1.6 & Simmerer et al.2004 \\
\hline 4934 & - & - & - & Alonso et al.1999 \\
\hline 4925 & 1.5 & -1.57 & 2.1 & $\begin{array}{l}\text { Pilachowski et al., } \\
1996\end{array}$ \\
\hline 4927 & - & -- & - & $\begin{array}{l}\text { Ramirez\&Melendez, } \\
2005\end{array}$ \\
\hline 4925 & 1.5 & -1.57 & 2.1 & Burris et al. , 2000 \\
\hline 5005 & - & - & - & $\begin{array}{l}\text { Gonzalez Hernandez } \\
\& \text { and Bonifacio, } \\
2009\end{array}$ \\
\hline
\end{tabular}

Our determinations corroborate with the mean values of the parameters within the errors: $<$ Teff $>=4955 \pm 44$ $\mathrm{K} ;<\log \mathrm{g}>=1.63 \pm 0.23 ;<[\mathrm{Fe} / \mathrm{H}]>=-1.45 \pm 0.12 ;<\mathrm{Vt}\rangle=$ $1.85 \pm 0.35 \mathrm{~km} / \mathrm{s}$.

In the atmospheres of metal-poor stars the deviations from the Local Thermodynamic Equilibrium (LTE) may influence to the stellar parameters and abundance of iron (see, e.g., Lind et al., 2012). But, for such stars Roederer et al. (2014) shown that the Fe II abundance determined in the LTE approaches agree with those ones under non-LTE approximations within $0.02 \mathrm{dex}$. The obtained results enabled Roederer et al. (2014) to adopt the iron abundance derived from the Fe II lines as an indicator of metallicity $[\mathrm{Fe} / \mathrm{H}]$. Our values of the iron abundance obtained from the Fe I and Fe II lines are almost similar, and we used the Fe I abundance as metallicity $[\mathrm{Fe} / \mathrm{H}]$.

\section{Abundances determination}

The elements abundances were determined using the LTE approximation and the atmosphere models by Castelli \& Kurucz (2004). The choice of model for each star was made by means of standard interpolation for $\mathrm{T}_{\text {eff }}$ and $\log \mathrm{g}$.

$\mathrm{Na}, \mathrm{Mg}, \mathrm{Sr}, \mathrm{Y}, \mathrm{Zr}, \mathrm{Mo}, \mathrm{Ba}, \mathrm{La}, \mathrm{Ce}, \mathrm{Pr}, \mathrm{Sm}, \mathrm{Eu}, \mathrm{Gd}$, Dy, Ho, Os, Th abundances were calculated employing the synthetic spectrum method by a new version of the STARSP software (Tsymbal, 1996) and new version of the VALD2018 line list (Kupka et al., 1999), Si, Ca, Sc abundances using EWs of lines and WIDTH9 code by Kurucz R. Two lines of Eu II $4129 \AA$ and $6645 \AA$ with HFS taking into account (Ivans et al., 2006) were used. The carbon abundance was determined using the molecular synthesis fitting in the region of $\mathrm{CH}$ (4300-4330 $\AA \AA$ ).

For the $\mathrm{Na}, \mathrm{Mg}$, and $\mathrm{Ba}$ abundances determinations we have used the NLTE corrections: the NLTE departures for $\mathrm{Na}, \mathrm{Mg}$ and $\mathrm{Al}$ at $[\mathrm{Fe} / \mathrm{H}] \sim-1.5$ varied from 0.03 to 0.15 dex depending on $\mathrm{T}_{\text {eff }}$ and $\log \mathrm{g}$ (Andrievsky et al., 2010); the NLTE correction for the Ba lines at $[\mathrm{Fe} / \mathrm{H}]$ close to 1.5 was about $0.1 \mathrm{dex}$ (Korotin et al., 2015) and for 4019 $\AA \mathrm{Th}$ line, for Sun it is $0.01 \mathrm{dex}$, and for $[\mathrm{Fe} / \mathrm{H}]$ near -1.5 it is about 0.05 dex (Mashonkina et al,. 2012).

The spectrum synthesis fitting of the Eu and Th lines to the observed profiles for star is shown in Figs. 3,4.
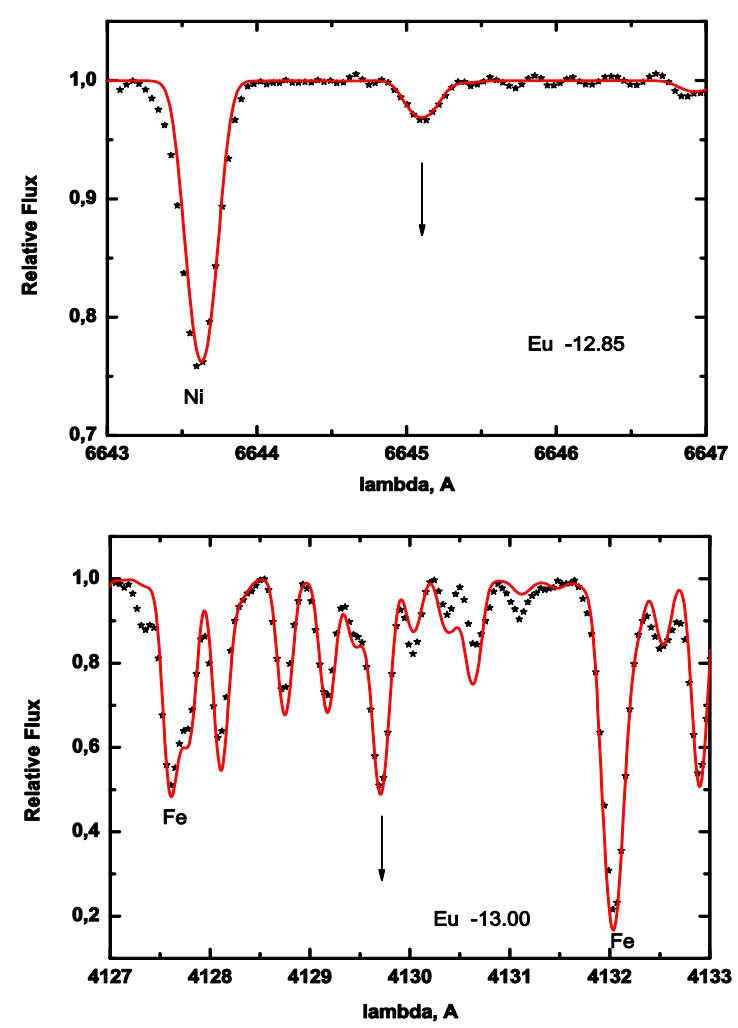

Figure 3. Observed (asterisk) and calculated (solid lines) spectra in the region of Eu II lines.

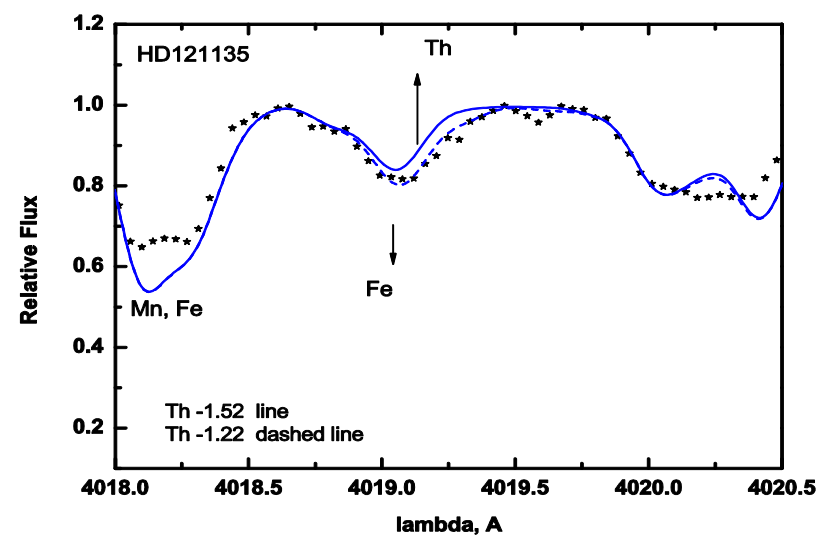

Figure 4. Observed (asterisk) and calculated (solid and dashed lines) spectra in the region of Th II line $4019 \AA$

To determine the systematic errors in the abundance estimates due to uncertainties in the atmospheric parameter determinations, we have derived the elemental abundances for the target star from several models with modified parameters $(\delta \mathrm{Teff}= \pm 100 \mathrm{~K} ; \delta \log \mathrm{g}= \pm 0.2 ; \delta \mathrm{Vt}= \pm 0.1)$. The total uncertainty due to the parameter and EW errors for the Fe I and Fe II are 0.11 and 0.12 , respectively. The determination accuracy for other elements varies from 0.10 to $0.18 \mathrm{dex}$.

We compared our abundance determinations with those obtained by other authors (Pilachowski et al., 1996, Burris et al., 2001; Simmerer et al., 2004). As seen our data are in good agreement with those of other authors (Table 2).

The elemental abundances $[\mathrm{El} / \mathrm{H}]$ as a function of the relevant atomic numbers for HD 121135 are depicted in Fig. 5. 


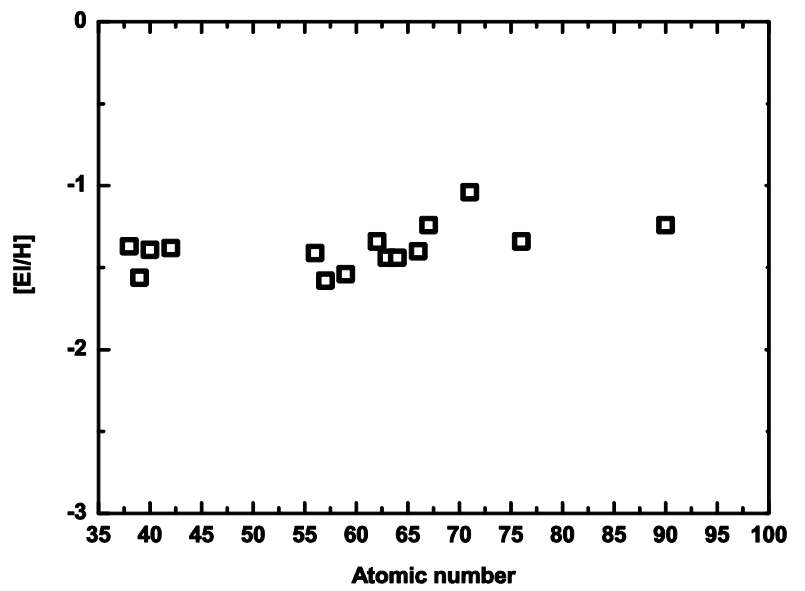

Figure 5. [El/H] vs. Atomic Number.

\section{Results and discussions}

We have studied HD 121135 both from the point of view of the advanced stages of stellar evolution of metalpoor stars, and in the context of n-capture elements enrichment.

\subsection{Stellar evolutionary effects}

Stars in the advanced stages of their evolution may be show some changes in the abundances of the certain chemical elements. Elements like $\mathrm{Li}, \mathrm{CNO}, \mathrm{Na}, \mathrm{Mg}$ and Al may be expected these changes, which is the subject of long-term researches in the atmospheres of galactic clusters giants (e.g. Charbonnel C., 1994; 1995). Table 2 presents the abundances of the $\mathrm{C}, \mathrm{Na}, \mathrm{Mg}, \mathrm{Si}, \mathrm{Ca}, \mathrm{Sc}, \mathrm{Ni}, \mathrm{Ba}$ and $\mathrm{La} / \mathrm{Eu}$ ratio obtained in our research, as well as those reported in Pilachowski et al. (1996), Burris et al. (2001) and Simmerer et al. (2004).

Table 2. C, Na, Mg, Si, Ca, Sc, Ni, Ba abundances and $\mathrm{La} / \mathrm{Eu}$ ratio

\begin{tabular}{|c|c|c|c|c|}
\hline Elem & our & $\begin{array}{l}\text { Pilachowski } \\
\text { et al., } 1996\end{array}$ & $\begin{array}{l}\text { Burris } \\
\text { et al., } \\
2001\end{array}$ & $\begin{array}{l}\text { Simmerer } \\
\text { et al., } \\
2004\end{array}$ \\
\hline$[\mathrm{C} / \mathrm{Fe}]$ & -0.53 & -- & -- & -0.45 \\
\hline$[\mathrm{O} / \mathrm{Fe}]$ & -- & -- & - & \\
\hline$[\mathrm{Na} / \mathrm{Fe}]$ & -0.04 & -0.10 & -- & \\
\hline$[\mathrm{Mg} / \mathrm{Fe}]$ & 0.43 & 0.44 & -- & \\
\hline$[\mathrm{A} / \mathrm{Fe}]$ & -- & -- & -- & \\
\hline$[\mathrm{S} / \mathrm{Fe}]$ & 0.50 & 0.48 & -- & \\
\hline$[\mathrm{Ca} / \mathrm{Fe}]$ & 0.27 & 0.30 & & \\
\hline$[\mathrm{Sc} / \mathrm{Fe}]$ & -0.13 & -0.06 & & \\
\hline$[\mathrm{Ni} / \mathrm{Fe}]$ & -0.02 & -0.24 & & \\
\hline$[\mathrm{Ba} / \mathrm{Fe}]$ & 0.19 & & 0.20 & \\
\hline $\log \mathrm{A}(\mathrm{La} \cdot \mathrm{Eu})$ & $0.46(0.40)$ & & & 0.37 \\
\hline
\end{tabular}

A detailed analysis of mixing along the red-giant branch field stars within the metallicity range of $-2 \leq$ $[\mathrm{Fe} / \mathrm{H}] \leq-1$ was carried out by Gratton et al. (2000). The abundances of light elements in lower-RGB stars (i.e. stars brighter than those with the first dredge-up luminosity and fainter than the RGB bump) are in agreement with the predictions made using classical evolutionary models.

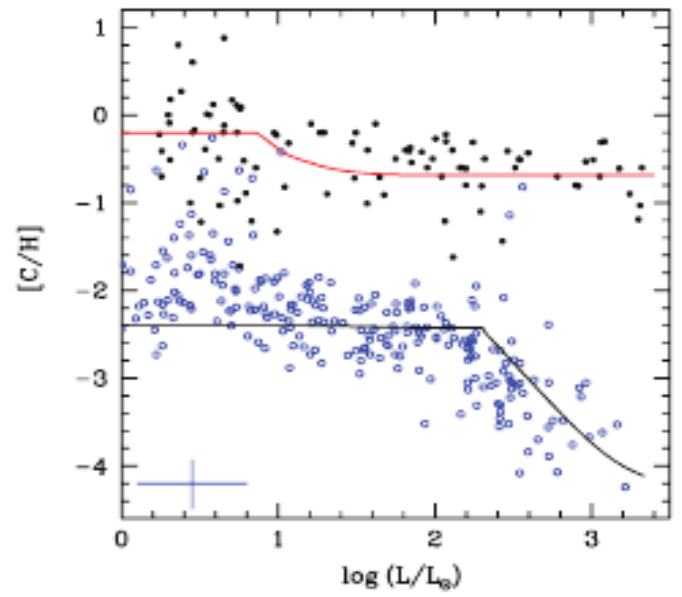

Figure 6. The carbon abundance vs. $\log \mathrm{L} / \mathrm{L}_{\odot}$; the figure corresponds to Figure 2 in Denissenkov\&Pinsonneault (2008).

LTE analysis of several extreme metal-poor (EMP) giants in order to understand the $\mathrm{CNO}$ abundance variations found in some, but not all EMP field giants, considering mixing beyond the first dredge-up in the standard stellar models performed by Spite et al. (2006). They found out a $\mathrm{C}-\mathrm{N}$ anti-correlation that corroborated the hypothesis that the surface abundances could be modified by the $\mathrm{CNO}$ processed material from the inner regions.

In our investigated star we found the carbon underabundance (Table 2) that may be agreement with the stellar evolution calculations and associated with canonical extra mixing (e.g., Denissenkov \& Pinsonneault, 2008; for the CMEP stars). Figure 5 in their paper illustrated variations in the surface $\mathrm{C}$ and $\mathrm{N}$ abundances (black curve) due to canonical extra mixing with the depth $\mathrm{rmix}=0: 045 \mathrm{R}_{\text {sol }}$ and rate $D_{\text {mix }}=0: 04 \mathrm{~K}$ in the RGB model with $M=0: 83$ $\mathrm{M}_{\mathrm{sol}}$ and $\mathrm{Z}=0: 0001$, but the extra mixing depth does not seems to depend strongly on the metallicity (Denissenkov \& VandenBerg, (2003). The authors called this universal non-convective mixing process "canonical extra mixing"

We compared our result with calculation of Denissenkov \& Pinsonneault (2008). For that we have computated the value of $\log \mathbf{L} / \mathbf{L} \boldsymbol{\Theta}=\mathbf{2 . 6 0}$ for HD121135 based on the classical formula:.

$$
\log \mathrm{L} / \mathrm{L}_{\odot}=\log \mathrm{M} * / \mathrm{M}_{\odot}+4 \log \mathrm{Teff} * / \mathrm{Teff}_{\odot}-\log \mathrm{g} * / \mathrm{g}_{\odot}
$$

were $\mathrm{Teff}_{\odot}=5780 \mathrm{~K}, \log \mathrm{g}_{\odot}=4.44$ and assuming the stellar mass $\mathrm{M}^{*}=0.85 \mathrm{M}_{\odot}$.

Fig. 6 presented the data by Denissenkov \& Pinsonneault (2008) for canonical extra mixing at $\log \mathrm{L} / \mathrm{L}_{\odot}>2.2$ (this figure correspond to black curves in Figures 2 in the cited paper). If we compare our values of $[\mathrm{C} / \mathrm{H}]=-2.00$ and $\log$ $\mathrm{L} / \mathrm{L}_{\odot}=2.60$ with the prediction reported in the aforementioned study, we can see that our star is located in the black curve which corresponds to canonical extra mixing for non-C-enhanced extremely metal-poor stars (Fig. 6). 


\subsection{Galactic n-capture element's enrichment}

Based on the values of the components of spatial velocities taken from (Simmerer et al. 2004 ): U lsr $(\mathrm{km} / \mathrm{s})=$ $8.2 \pm 11.1 ; \mathrm{V}$ lsr $(\mathrm{km} / \mathrm{s})=-169.5 \pm 24.4 ; \mathrm{W} 1 \mathrm{sr}(\mathrm{km} / \mathrm{s})=$ $111.3 \pm 1.9$ and the criterion for separating of stars belonging to the thick disk and the halo, for which the velocity component is equal $-\mathrm{Vlsr}=175 \mathrm{~km} / \mathrm{c}$ (Marsakov, Borkova 2005), we can classify this star after study as a halo rather than thick disc.

The obtained pattern of the abundances of elements depending on their atomic numbers (for the elements with AN > 50, Fig.5), the abundance slightly increases with increasing atomic number) is in agreement with the results obtained by Sneden et al. (2003) for the star CS 22892052 exhibiting a scaled solar system r-process abundance (as stars with no r-process enriched).

We compare also obtained $\mathrm{Sr}, \mathrm{Ba}, \mathrm{Eu}$ abundance with indicators of strong r-process evidence. Our values of $[\mathrm{Eu} / \mathrm{Fe}]=0.06,[\mathrm{Ba} / \mathrm{Eu}]=0.13,[\mathrm{Sr} / \mathrm{Ba}]=-0.05$ do not support the definition of a star as enriched with $\mathrm{r}$-process elements (r-I stars: $[\mathrm{Eu} / \mathrm{Fe}]>0.3,[\mathrm{Ba} / \mathrm{Eu}]<0.0,[\mathrm{Sr} / \mathrm{Ba}]>0.5)$.

\section{Conclusion}

- Carbon abundance confirms the operating of canonical extra mixing (Denissenkov\&Pinsonneault 2008).

- The abundances of some n-capture elements were determined for the first time, including $\mathrm{Th}$ $[\mathrm{Th} / \mathrm{Fe}]=0.26$

- Behavior of n-capture element's abundances don't show significant trend with atomic number increasing.

- Our values of $[\mathrm{Eu} / \mathrm{Fe}]=0.06,[\mathrm{Ba} / \mathrm{Eu}]=0.13$, $[\mathrm{Sr} / \mathrm{Ba}]=-0.05$ do not support the definition of a star as enriched with r-process elements (r-I stars: $[\mathrm{Eu} / \mathrm{Fe}]>0.3,[\mathrm{Ba} / \mathrm{Eu}]<0.0,[\mathrm{Sr} / \mathrm{Ba}]>0.5)$.

\section{References}

Alonso et al.: 1999, A\&AS, 140, 261.

Andrievsky et al.: 2010, $A \& A, \mathbf{5 0 9}$, id. A88.

Arcones A., Thielemann F-K.: 2013, JPhG, 40, id. 013201.

Barnes. et al., 2008, SPIE 7014, 70140K.

Beers T., Christlieb N.: 2005, ARA\&A, 43, 531.
Bramall et al.: 2010, SPIE 7735, 77354F.

Bramall. et al.: 2012, SPIE 8446, 84460A.

Burris et al.: 2000, ApJ, 554, 302.

Buckley D.A.H., Swart G.P., Meiring J.G.: 2006, SPIE, 6267.

Castelli F., Kurucz R.: 2004, ArXiv Astrophysics e-prints astro-ph/0405087.

Charbonnel C.: 1994, A\&A, 282, 811.

Charbonnel C.: 1995, ApJ, 453, 41.

Coelho P.R.T.: 2014, MNRAS, 440, 1027.

Crause et al.: 2014, SPIE 9147. 91476T.

Crawford et al.: 2010, SPIE 7737, 773725.

Denissenkov P., Pinsonneault: 2008, ApJ, 679, 1541.

Denissenkov P., VandenBerg D. A.: 2003, ApJ, 593, 509.

Galazutdinov G.: 2007, http://gazinur.com/DECHsoftware.html

Gonzalez Hernandez J., Bonifacio P.: 2009, A\&A, 497, 497.

Gratton, R.: 1989, A\&A, 208, 171.

Frebel A.: 2018, ARNPS, 68, 237.

Frebel A., Norris J.: 2015, ARA\&A, 53, 631.

Hansen et al.: 2018, ApJ, 858, 92.

Hill et al.: 2002, $A \& A, \mathbf{3 8 7}, 560$.

Holmbeck et al.: 2018, ApJ, 859, id. L24.

Ivans et al.: 2006, ApJ, 645, 613 .

Korotin et al.: 2015, $A \& A, \mathbf{5 8 1}, 70$.

Kupka et al.: 1999, A\&ASuppl., 138, 119.

Lattimer J., Schramm D.: 1974, ApJ, 192, 145.

Lind et al.: 2012, MNRAS, 427, 50.

Lippuner et al.: 2017, MNRAS, 472, 904.

Marsakov V., Borkova T.: 2005, AstL, 31, 515.

Mashonkina et al.: 2014, $A \& A, \mathbf{5 6 9}, 43$.

Mashonkina et al.: 2012, $A \& A, \mathbf{5 4 0}, 98$.

Nishimura et al.: 2017, ApJ. 836, 21.

O'Donoghue D. et al.: 2006, MNRAS, 372, 151.

Pilachowski et al.: 1996, AJ, 111, 1689.

Ramirez I., Melendez J.: 2005, ApJ, 626, 465.

Roederer et al.: 2014, $A J$, 147, 136.

Rosswog et al.: 2014, MNRAS, 439, 757.

Simmerer et al.: 2004, ApJ, 617, 1091.

Sneden et al.: 1996, ApJ, 467, 819.

Sneden et al.: 2003, ApJ, 591, 936.

Spite et al.: 2006, $A \& A, \mathbf{4 5 5}, 291$.

Spite et al.: 2018, $A \& A, \mathbf{6 1 1}, 30$.

Tsujimoto T., Nishimura N.: 2015, ApJ, 811, 10.

Tsymbal V.: 1996, ASP Conf. Ser., 108, 198.

Winteler et al.: 2012, ApJ, 750, 22.

Yong et al.: 2013, ApJ, 762, 26. 